\title{
Pretraživanje zdravstvenih informacija na internetu - implikacije za zdravstvenu anksioznost kod starijih osoba
}

\author{
Branka Bagarić \\ Hrvatsko udruženje za bihevioralno-kognitivne terapije, Zagreb, Hrvatska \\ Nataša Jokić-Begić \\ Sveučilište u Zagrebu, Filozofski fakultet, Odsjek za psihologiju, Zagreb, Hrvatska
}

\begin{abstract}
Sažetak
Pretraživanje o zdravlju na internetu postalo je vrlo rašireno. Kako starije osobe imaju više zdravstvenih problema, mogle bi postati sve veći konzumenti digitalnih zdravstvenih sadržaja. No, budući da imaju slabije računalne vještine te da nisu naviknute na ulogu „osnaženog pacijenta“, mogle bi doživjeti pretjeranu zabrinutost dok pretražuju o svojim simptomima. Istraživanja sugeriraju da je pretraživanje o zdravlju na internetu potencijalni rizični faktor za patološku zdravstvenu anksioznost, a možda na poseban način djeluje upravo na starije osobe. Istraživanja o pretraživanju kod starijih malobrojna su i uglavnom provedena bez jasnog teorijskog okvira što otežava smislenu interpretaciju i integraciju njihovih nalaza. Stoga je cilj ovoga preglednog rada ponuditi takav teorijski okvir (Leventhalov model zdravorazumske regulacije) te dati pregled nalaza dosadašnjih istraživanja u području integrirajući ih u predloženi model. Ovaj model predviđa da dob i dobne promjene u doživljaju sebe rezultiraju promjenama u zdravstvenim kognicijama i ponašanjima. Pretraživanje o zdravlju na internetu može se konceptualizirati kao strategija suočavanja i sa zdravstvenom prijetnjom i emocionalnom neugodom, a koja ima posljedice na kognitivne reprezentacije bolesti (identitet, uzrok, posljedice, mogućnost kontrole i vremensku dimenziju), zdravstvena ponašanja i ishode. Polazeći od pretpostavki modela, raspravljeno je kako pretraživanje može rezultirati zdravstvenom anksioznošću. Na kraju su pružene smjernice za buduća istraživanja i razmotrene njihove praktične implikacije.
\end{abstract}

Ključne riječi: pretraživanje o zdravlju na internetu, stariji, zdravstvena anksioznost, model zdravorazumske regulacije, kiberohondrija

Branka Bagarić, Hrvatsko udruženje za bihevioralno-kognitivne terapije, Šenoina 25, 10000 Zagreb, Hrvatska. E-pošta: branka.bagaric1 @ gmail.com 


\section{Uvod}

Čak $60 \%$ osoba pretražuje o zdravlju na internetu (European Commission, 2015), a čini se da će ta brojka u budućnosti biti sve veća (npr. Bujnowska-Fedak, Waligóra i Mastalerz-Migas, 2019; Prestin, Vieux i Chou, 2015). Ne iznenađuje da su pretraživanju o zdravlju sklonije osobe lošijeg zdravlja (Lee, Boden-Albala, Larson, Wilcox i Bakken, 2014). Kako s dobi raste prevalencija kroničnih bolesti (Ward i Schiller, 2013), starije bi osobe mogle imati veću potrebu za zdravstvenim informacijama. Iako stariji aktualno manje od drugih dobnih skupina pretražuju o zdravlju na internetu (Kontos, Blake, Chou i Prestin, 2014), s obzirom na to da su najbrže rastuća skupina korisnika (Wagner, Hassanein i Head, 2010; NTIA, 2011), te da populacija stari, u budućnosti bi mogli postati glavni konzumenti digitalnih zdravstvenih informacija.

Stariji često imaju složene zdravstvene potrebe, dok istovremeno s dobi opadaju zdravstvena pismenost (Baker, Gazmararian, Sudano i Patterson, 2000) i računalne vještine (Stronge, Rogers i Fisk, 2006). Pored toga, osobe koje danas imaju 65 i više godina odrasle su u kontekstu drugačijih zdravstvenih politika. Dok se u suvremenom društvu potiče aktivna uloga pacijenta u brizi za zdravlje (Lewis, 2006; Thistlethwaite, 2005), stariji su skloniji tradicionalnim ulogama liječnika i pacijenta (Campbell, 2009; Longtin i sur., 2010). Veće zdravstvene potrebe, manje vještine i veći pritisak k osobnoj odgovornosti za zdravlje „otvaraju vrata“ anksioznosti kod starijih dok se pokušavaju snaći u opsežnom i dinamičnom digitalnom krajoliku zdravstvenih informacija.

Istraživanja o informiranju o zdravlju na internetu kod starijih malobrojna su i uglavnom provedena bez teorijskog okvira koji bi omogućio smislenu interpretaciju i integraciju nalaza te usmjerio buduća istraživanja. Stoga su ciljevi ovog rada: 1) predložiti primjenu Leventhalova modela zdravorazumske regulacije za razumijevanje uloge i posljedica internetskog pretraživanja zdravstvenih informacija kod starijih osoba i 2) razmotriti potencijalne posljedice pretraživanja zdravstvenih informacija na internetu na zdravstvenu anksioznost starijih osoba. No, prvo će biti opisan širi okvir za razumijevanje djelovanja rizičnih faktora i pojave psihopatologije tijekom razvoja te dan pregled nalaza istraživanja o mogućoj ulozi pretraživanja o zdravlju na internetu u razvoju zdravstvene anksioznosti.

\section{Pretraživanje zdravstvenih informacija i zdravstvena anksioznost u razvojnoj perspektivi}

Pretraživanje zdravstvenih informacija podrazumijeva načine na koje osoba dolazi do informacija o zdravlju, promociji zdravlja, zdravstvenim rizicima i bolestima (Lambert i Loiselle, 2007). Svrha je takvog ponašanja smanjenje neizvjesnosti u vezi sa zdravljem te konstruiranje socijalnog i osobnog značenja zdravlja (Tardy i Hale, 1998). Možemo razlikovati pasivno primanje zdravstvenih 
informacija i njihovo aktivno traženje (Longo, 2005). Ključni je aspekt pretraživanja zdravstvenih informacija na internetu aktivna uloga pojedinca u traženju i odabiru željenih informacija, pa čak i sudjelovanje u njihovu kreiranju. Za razliku od drugih izvora zdravstvenih informacija, poput knjiga, časopisa ili televizije, sadržaj na internetu slabije je reguliran i ,propusniji“ za netočne, odnosno neprovjerene informacije. U skladu s tim, istraživanja sugeriraju da je njegova kvaliteta raznolika (Alsaiari, Joury, Aljuaid, Wazzan i Pines, 2016; Grohol, Slimowicz i Granda, 2013; Hirsch, Aggarwal, Barker, Davis i Duffy, 2017), a stil pisanja kompleksan (Hirsch i sur., 2017; McInnes i Haglund, 2011). Zbog toga do izražaja dolaze karakteristike korisnika - njihova motivacija, a onda i sposobnost da pronađu kvalitetne informacije, razumiju ih i iskoriste - koje se mogu razlikovati ovisno o dobi.

Pretraživanje o zdravlju na internetu može imati pozitivne posljedice, poput primjerice informiranja i dobivanja socijalne podrške (Ziebland i Wyke, 2012) te doživljaja kontrole, samopouzdanja i osnaženosti tijekom liječničkog pregleda (Tan i Goonawardene, 2017). No, pretraživanje može imati i negativne posljedice. Naime, internetske tražilice imaju tendenciju nuditi rijetke i zastrašujuće dijagnoze kao rezultate pretrage o uobičajenim simptomima, što može dovesti do nepotrebne zabrinutosti za zdravlje (White i Horvitz, 2009a). Nekoliko je istraživanja sugeriralo da bi pretraživanje o zdravlju na internetu moglo biti rizično ponašanje za razvoj pretjerane zdravstvene anksioznosti (Bessière, Pressman, Kiesler i Kraut 2010; te Poel, Baumgartner, Hartmann i Tanis, 2016). Zdravstvena anksioznost podrazumijeva zabrinutost za zdravlje koja se javlja u odsustvu bolesti (Lucock i Morley, 1996). Može se kretati od blage do ekstremne (Asmundson, Taylor i Cox, 2001), kada ulazi u dijagnostičku kategoriju anksioznog poremećaja zbog bolesti prema klasifikaciji DSM-5 (American Psychiatric Association, 2013).

Starije bi osobe mogle biti osobito ranjive na pojavu anksioznosti prilikom pretraživanja. Naime, zdravstvena anksioznost raste s dobi (Bleichhardt i Hiller, 2007), pa je hipohondrija (stariji naziv za dijagnozu pretjerane zdravstvene anksioznosti) jedan od najčešćih psihičkih poremećaja kod starijih osoba (Ghubach i sur., 2010), a prosječna je dob u kojoj se dijagnosticira čak 57 godina (El-Gabalawy, Mackenzie, Thibodeau, Asmundson i Sareen, 2013).

Perspektiva razvojne psihopatologije bavi se razmatranjem djelovanja nekog faktora rizika u cjeloživotnoj perspektivi ispitujući kako različiti razvojni zadaci mogu dovesti do novih simptoma te kako isti stresor može rezultirati različitim ishodima ovisno o razvojnom periodu u kojem se pojavi (Cicchetti i Cohen, 2006). Naime, faktori rizika mogu imati različito djelovanje ovisno o dobi u kojoj se pojave, pri čemu ono može biti intenzivnije, manje intenzivno, ali i kvalitativno drugačije (Rutter, 1988). Takva istraživanja pomažu u razumijevanju mehanizma djelovanja nekoga rizičnog čimbenika i procesa razvoja psihopatologije (Cicchetti i Cohen, 2006).

Razvoj predstavlja stalnu interakciju između pojedinca i okoline pri čemu se i pojedinac i okolina neprestano mijenjaju (Cicchetti i Cohen, 2006). Internet je 
jedinstven primjer digitalne, globalno prisutne i izrazito dinamične okoline. Tako korisnik na internetu ima mogućnost odabira sadržaja (npr. stranica, videa), evaluiranja sadržaja (npr. „likeanje“, komentiranje) i izrade sadržaja (npr. blogovi, forumi). U užem smislu, ti izbori mogu ovisiti o trenutnom stanju u kojem se pojedinac nalazi, poput tjelesnih simptoma koje aktualno uočava i načina na koji te simptome doživljava. No, u širem smislu, ti izbori mogu ovisiti o fazi razvoja u kojoj se pojedinac nalazi: o njegovoj dobi, aktualnim razvojnim zadacima, iskustvima specifičnima njegovoj dobnoj skupini i kohorti. Konzumacija digitalnih zdravstvenih sadržaja može zauzvrat ostaviti posljedice na pojedinca, u vidu novih učenja (Fox i Rainie, 2002; Moreland, French i Cumming, 2015), promjene zdravstvenih navika (Fox i Jones, 2009), porasta ili pada anksioznosti (White i Horvitz, 2009b), a potencijalno i razvoja patološke zdravstvene anksioznosti.

\section{Uloga pretraživanja zdravstvenih informacija na internetu u razvoju zdravstvene anksioznosti}

Prilikom konceptualizacije etiologije nekoga psihopatološkog fenomena obično o potencijalnim antecedentima govorimo kao o rizičnim čimbenicima, no u užem smislu možemo razlikovati četiri mjere rizika (Kazdin, Kraemer, Kessler, Kupfer i Offord, 1997). Korelat je varijabla koja pokazuje povezanost ili zajedničko pojavljivanje $\mathrm{s}$ psihopatološkim fenomenom, ali bez implikacija o vremenskom slijedu. Rizični je čimbenik varijabla za koju je utvrđeno da prethodi psihopatološkom ishodu. Marker je faktor rizika koji nije uzrok psihopatološkog ishoda iako mu vremenski prethodi, jer je njihova povezanost rezultat treće varijable. Kauzalni rizični čimbenik varijabla je čije mijenjanje rezultira promjenom u vjerojatnosti pojave psihopatološkog ishoda te se smatra jednim od njegovih uzorka. Kakav status, kao mjera rizika, ima pretraživanje zdravstvenih informacija na internetu u razvoju zdravstvene anksioznosti, može se procijeniti na temelju empirijskih nalaza (Kazdin i sur., 1997). U ovom će poglavlju biti prikazani rezultati istraživanja koji su provedeni s osobama različite dobi, a ne specifično kod starijih, da bi se raspravila uloga pretraživanja u pojavi zdravstvene anksioznosti općenito, dok će se naredna poglavlja usmjeriti na populaciju starijih osoba.

Veći je broj istraživanja uputio na pozitivnu povezanost između učestalosti pretraživanja o zdravlju na internetu i zdravstvene anksioznosti (Baumgartner i Hartmann, 2011; Muse, McManus, Leung, Meghreblian i Williams, 2012; Singh i Brown, 2014). Utvrđeno je i da postoji pozitivna povezanost između trajanja pojedine sesije pretraživanja o zdravlju i zdravstvene anksioznosti (Muse i sur., 2012) te između ukupnog vremena provedenog u pretraživanju o zdravlju i zdravstvene anksioznosti (Singh i Brown, 2014). Prema tome, pretraživanje o zdravlju na internetu je korelat zdravstvene anksioznosti. No, na temelju nalaza ovih presječnih studija nije moguće utvrditi dovodi li pretraživanje o zdravlju na internetu do porasta zdravstvene anksioznosti ili zdravstvena anksioznost potiče na pretraživanje. Stoga su nužna longitudinalna istraživanja. 
Do sada se u literaturi nalaze dva longitudinalna istraživanja u ovom području. U prvom istraživanju zdravstvena anksioznost i učestalost pretraživanja na internetu izmjerene su u četiri točke mjerenja u razmaku od po dva mjeseca (te Poel i sur., 2016). Utvrđeno je da porast u pretraživanju o zdravlju predviđa kasniji porast u zdravstvenoj anksioznosti u nekliničkoj populaciji. No, utvrđeno je i obrnuto, da porast u zdravstvenoj anksioznosti predviđa kasniji porast u učestalosti pretraživanja. Čini se da se ove varijable međusobno pojačavaju, no nije jasno čime ciklus započinje, zabrinutošću za zdravlje zbog nekog simptoma ili pretraživanjem o zdravlju iz znatiželje (te Poel i sur., 2016). U drugom istraživanju utvrđeno je da porast pretraživanja o zdravlju praćen porastom depresivnosti 12 do 36 mjeseci kasnije (Bessière, Pressman, Kiesler i Kraut, 2010) uz kontrolu promjena u somatskom zdravlju. Autori pretpostavljaju da je porast depresivnosti posljedica nepotrebne zabrinutosti za zdravlje koja proizlazi iz pretraživanja. Dakle, postoje indikacije da je pretraživanje o zdravlju na internetu faktor rizika za zdravstvenu anksioznost, no potrebna su dodatna istraživanja.

Čak i ako pretraživanje prethodi zdravstvenoj anksioznosti, ne mora biti njezin uzrok. Obje varijable mogu biti posljedica „treće varijable“, primjerice druge psihičke i somatske bolesti. Utvrđeno je da povezanost između zdravstvene anksioznosti i pretraživanja o zdravlju na internetu postoji i uz kontrolu dobi, spola, opće učestalosti korištenja interneta i zaposlenja u zdravstvenom sektoru (Baumgartner i Hartmann, 2011; Muse i sur., 2012). Samo se dio njihove povezanosti može pripisati generaliziranoj anksioznosti i depresivnosti (Singh i Brown, 2014). K tome, možda nije opravdano statistički izuzeti generaliziranu anksioznost i depresivnost jer su oni vjerojatno dio kliničke slike zdravstvene anksioznosti (Scarella, Laferton, Ahern, Fallon i Barsky, 2016). No, navedena istraživanja nisu kontrolirala postojanje somatskih bolesti koje mogu povećati anksioznost oko zdravlja te istovremeno potaknuti pretraživanje $\mathrm{s}$ ciljem informiranja i lakšeg suočavanja s bolešću.

Ako je pretraživanje o zdravlju kauzalni rizični čimbenik za zdravstvenu anksioznost, manipulacija pretraživanjem trebala bi izazvati promjene $u$ zdravstvenoj anksioznosti. Pokazalo se da pretraživanje na internetu o uznemirujućem simptomu koji su sudionici ranije doživjeli (Singh i Brown, 2016) te čitanje o izmišljenoj bolesti na internetu (Baumgartner i Hartmann, 2011) može rezultirati porastom anksioznosti. No, u opisanim istraživanjima ispitivan je utjecaj pretraživanja na trenutnu razinu anksioznosti, a ne na razvoj stabilne kliničke razine zdravstvene anksioznosti, pa je taj porast možda privremen i od malog kliničkog značaja. Dakle, za sada je teško reći je li pretraživanje o zdravlju kauzalni rizični čimbenik za zdravstvenu anksioznost.

Zaključno, postoje empirijski dokazi da je pretraživanje o zdravlju na internetu barem korelat, a potencijalno i rizični čimbenik za zdravstvenu anksioznost. Kada je riječ specifično o populaciji starijih, istraživanja o ulozi interneta na zdravstvena doživljavanja i ponašanja još uvijek su u svojoj ranoj fazi. U pravilu se radi o 
istraživanjima koja su usmjerena na opis fenomena pretraživanja zdravstvenih informacija, bez razvijanja teorijskih modela koji bi ponudili okvir za smislenu interpretaciju nalaza. Model zdravorazumske regulacije Levanthala i suradnika (Leventhal, Brissette i Leventhal, 2003; Leventhal i Crouch, 1997; Martin, Rothrock, Leventhal i Leventhal, 2003), za razliku od drugih relevantnih modela iz područja zdravstvene i kliničke psihologije (za pregled vidjeti npr. Bagarić i Jokić-Begić, 2019), specificira dobne promjene u zdravstvenim kognicijama i ponašanjima, pa nudi smislen teorijski okvir za razumijevanje uzroka i posljedica pretraživanja zdravstvenih informacija na internetu upravo kod starijih, potencijalno ranjivije, a istovremeno sve veće populacije korisnika.

\section{Leventhalov model zdravorazumske regulacije - promjene u konceptu zdravlja i bolesti u starijoj životnoj dobi}

Prema modelu zdravorazumske regulacije Leventhala i suradnika (Leventhal i sur., 2003; Martin, Rothrock, Leventhal i Leventhal, 2003) kada se uoči neka zdravstvena smetnja, paralelno se odvijaju dva procesa, kognitivni, koji uključuje reprezentaciju zdravstvene prijetnje te strategije usmjerene na suočavanje $\mathrm{s}$ tom prijetnjom, i emocionalni, koji podrazumijeva strah i distres te strategije usmjerene na suočavanje s tim emocijama (Slika 1.). Strategije usmjerene na kontrolu prijetnje i emocionalne neugode zasebno doprinose zdravstvenim ponašanjima i ishodima, pa mogu poticati i oprečna ponašanja (npr. odlazak na liječnički pregled radi zaštite od opasnosti i njegovo izbjegavanje zbog straha od dijagnosticiranja ozbiljne bolesti).

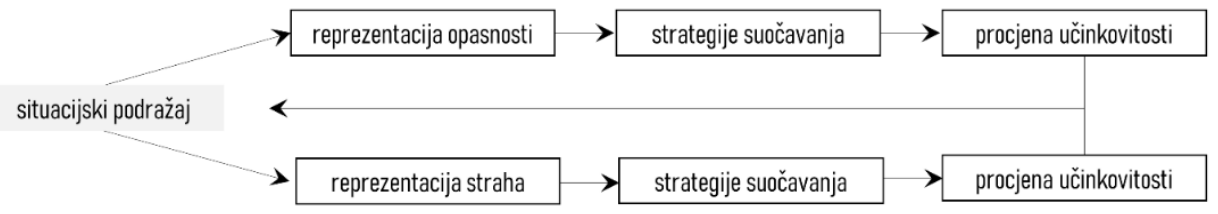

Slika 1. Model zdravorazumske regulacije zdravlja i bolesti (Leventhal i sur., 2003).

Kognitivna reprezentacija zdravstvene prijetnje uključuje nekoliko atributa: identitet (simptomi i etikete), uzrok, potencijalne posljedice, mogućnost kontrole te vremensku dimenziju (Martin i sur., 2003), koje usmjeravaju strategije suočavanja. Primjerice, ako pojedinac vjeruje da je glavobolja (identitet) znak tumora (uzrok), da bi posljedice mogle biti invaliditet i smrt (potencijalne posljedice) i da će nastupiti brzo (vremenska dimenzija) te da mu samo operacija može spasiti život (mogućnost kontrole), jasno je da će strategija biti - otići liječniku. Nakon primjene strategija suočavanja pojedinac procjenjuje njihovu učinkovitost $\mathrm{i}$ te informacije pohranjuje $\mathrm{u}$ reprezentacije bolesti. Dakle, reprezentacije bolesti i strategije suočavanja mijenjaju se kroz životna iskustva. 
Sukladno tome, autorice Leventhal i Crouch (1997) sugeriraju da starenjem dolazi do promjena u reprezentacijama bolesti i odabiru strategija suočavanja sa zdravstvenim prijetnjama što rezultira različitim zdravstvenim ishodima. Dob $i$ dobne promjene и ројти о sebi mogu utjecati na sve elemente modela: simptome, reprezentaciju bolesti, emocionalna stanja, načine suočavanja te procjenu ishoda (Slika 2.).

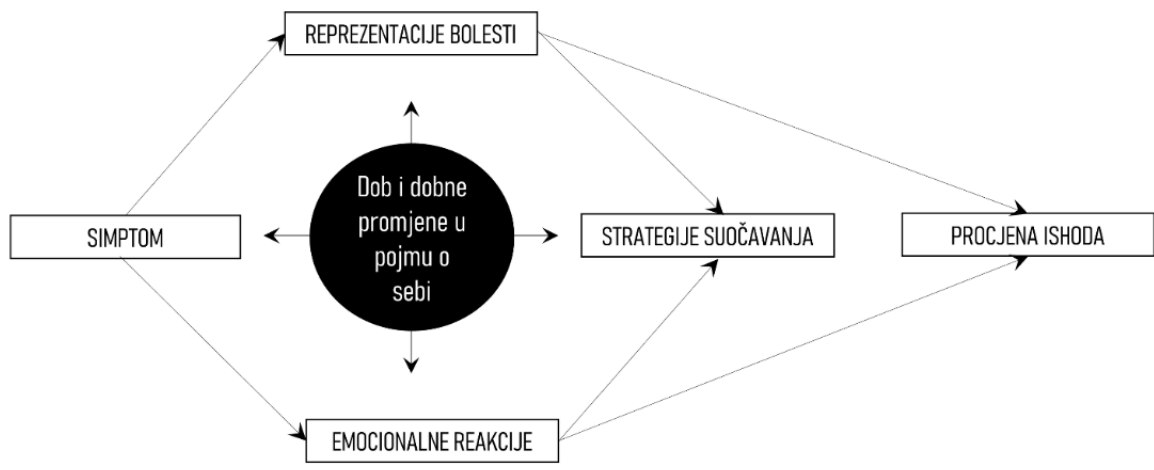

Slika 2. Dob kao moderirajući faktor u modelu reprezentacije bolesti (Leventhal i Crouch, 1997).

Dobne promjene u pojmu o sebi nastaju zbog svijesti o tjelesnim znakovima starenja te informacija o smrti i bolesti vršnjaka. Uslijed toga starije osobe sklone su povećanom doživljaju ranjivosti (Prohaska, Leventhal, Leventhal i Keller, 1985). U skladu s tim pokazalo se da stariji više brinu o zdravlju od mlađih (Hunt, Wisockia i Yanko, 2003), a aktivacija sheme o starosti kod starijih dovodi do veće usmjerenosti na simptome (Poon i Knight, 2009). Doživljaj ranjivosti potiče korištenje strategija suočavanja koje smanjuju rizik, poput redovitih pregleda i zdravije prehrane (Prohaska i sur., 1985).

No, istovremeno, starije bi osobe mogle biti manje sklone neki simptom pripisati bolesti. Naime, stariji češće imaju kronične bolesti (Bradley i Hughes, 2013) praćene blažim simptomima koji se razvijaju postupno, pa ih je teško razlučiti od promjena koje prirodno prate starenje. Stoga su stariji skloniji nejasne simptome pripisati starenju, a ne bolesti (Prohaska i sur., 1985) što može rezultirati lošijim zdravstvenim ishodima (Sarkisian, Lee-Henderson i Mangione, 2003; Wurm, Warner, Ziegelmann, Wolff i Schüz, 2013).

Uzevši u obzir promjene $u$ doživljaju simptoma i zdravstvenim ponašanjima $u$ starijoj dobi, uloga pretraživanja o zdravlju na internetu može biti specifična u ovoj populaciji. 


\section{Integracija empirijskih nalaza u model zdravorazumske regulacije kod starijih - implikacije za zdravstvenu anksioznost}

Da bismo razumjeli ulogu pretraživanja o zdravlju na internetu u razvoju zdravstvene anksioznosti kod starijih osoba, integrirat ćemo rezultate dosadašnjih istraživanja iz ovog područja u model zdravorazumske regulacije kod starijih. Ovdje će biti prikazani rezultati pretraživanja upravo kod starijih osoba, a ponegdje će, za usporedbu, biti navedeni nalazi koji vrijede za mlađe osobe.

U okviru opisanog modela pretraživanje o zdravlju može se konceptualizirati kao strategija suočavanja usmjerena na kontrolu prijetnje (simptom), ali i emocionalne neugode (straha). Istovremeno, informacije o zdravlju prikupljene na internetu mogle bi utjecati na reprezentacije zdravlja i bolesti te zdravstvena ponašanja (Bass, 2003). Shematski prikaz integracije postojećih nalaza u ovaj model prikazan je na Slici 3.

\section{Pretraživanje o zdravlju na internetu kao strategija suočavanja s prijetnjom}

Učestalost pretraživanja. Ako starija osoba neki simptom procijeni kao prijetnju, ima na raspolaganju više strategija suočavanja, poput odlaska liječniku, razgovora s bližnjima ili pretraživanja na internetu. Između 40 \% i 70 \% starijih se barem nekad odlučuje za internet (Chang i Im, 2014; Flynn, Smith i Freese, 2006; Fox, 2011; Medlock i sur., 2015). Istraživanja redovito pokazuju da starije osobe u manjoj mjeri od drugih koriste internet da bi se informirale o zdravlju (Cotten i Gupta, 2004; Gallagher i Doherty, 2009; Jacobs, Amuta i Jeon, 2017), iako je i za njih pretraživanje o zdravlju jedna od ključnih online aktivnosti (Fox, 2011). Stariji, za razliku od mlađih odraslih, rijetko internet vide kao jedan od najvažnijih izvora zdravstvenih informacija (Dart, 2008). Manja upotreba ove strategije kod starijih može biti efekt kohorte, odnosno činjenice da su današnje generacije starijih slabije upoznate s tehnologijom (Stronge, Rogers i Fisk, 2006). Međutim, kada je riječ o starijim osobama koje koriste internet, za čak $44 \%$ njih internet je preferirani izvor informiranja kada imaju neko zdravstveno pitanje (Medlock i sur., 2015). Budući da stariji doživljavaju više simptoma, moguće je da će buduće generacije starijih više odabirati internet kao strategiju suočavanja, zbog njezine dostupnosti i niske cijene.

Okidač pretraživanja. Pokazalo se da među osobama u dobi od 63 do 66 godina koje pretražuju o zdravlju na internetu otprilike trećina to čini nakon, a šestina prije posjeta liječniku (Flynn i sur., 2006). Ovaj nalaz potvrđen je na uzorku još starijih osoba, prosječne dobi od 72 godine (Medlock i sur., 2015), gdje se također pokazalo da je većina sudionika o zdravlju pretraživala nakon posjeta liječniku, a upola manje prije posjeta ili da odluče je li liječnički pregled uopće potreban. Slični su rezultati dobiveni i u općoj populaciji (Fox, 2000). Stariji navode da im pretraživanje pomaže da postave dobra pitanja liječniku i da bolje razumiju ono što im je liječnik rekao na pregledu (Taha, Sharit i Czaja, 2009). 


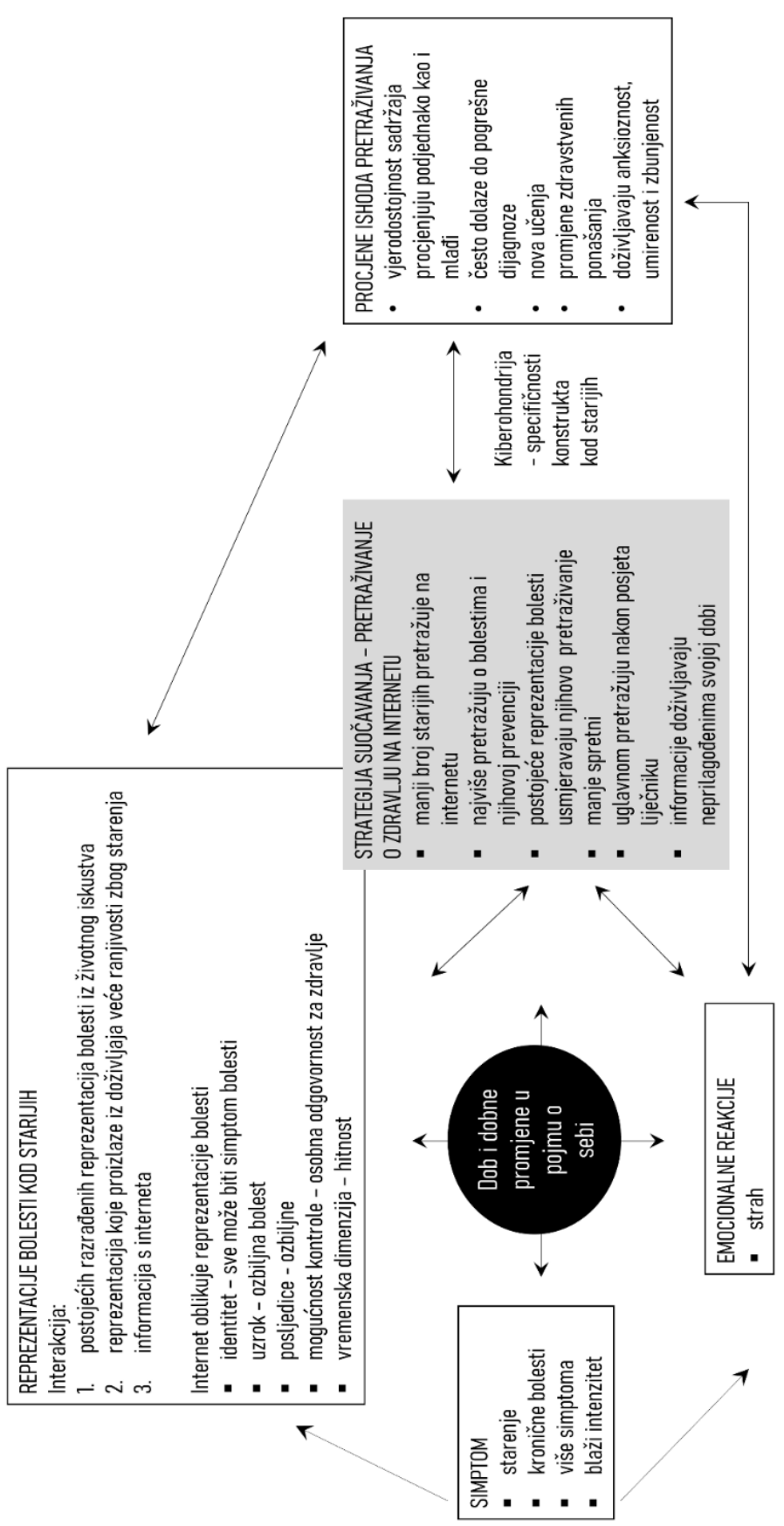

Slika 3. Shematski prikaz integracije empirijskih nalaza o pretraživanju o zdravlju na internetu kod starijih osoba u modelu zdravorazumske regulacije. 
Teme pretraživanja. Kada se odluče na pretraživanje o zdravlju na internetu, osobe različite dobi istraživat će o različitim temama. Te razlike mogu biti posljedice triju skupina čimbenika kojima se pojedinac prilagođava tijekom cjeloživotnog razvoja: utjecaji povezani s dobnom skupinom, a koji uglavnom imaju predvidiv tijek; utjecaji povezani s povijesnim razdobljem te nenormativni utjecaji specifični manjem broju pojedinaca, nepredvidivog tijeka (Baltes, 1987). Primjerice, mladi najviše pretražuju o spolnom zdravlju, trudnoći i kontracepciji (Borzekowski i Rickert, 2001; Buhi, Daley, Fuhrmann i Smith, 2009), a stariji o bolestima (54 \%) i zdravim stilovima života (35\%), poput vježbanja i zdrave prehrane (Chang i Im, 2014). U usporedbi s drugim dobnim skupinama, stariji od 65 godina u manjem postotku pretražuju o kontroli tjelesne težine i zdravstvenom osiguranju, a praktički ne pretražuju o trudnoći i porodu (Fox, 2011; Fox i Duggan, 2013). Pored toga, zanimaju ih informacije o liječnicima, bolnicama i domovima za starije (Taha i sur., 2009). Ove razlike u interesima odražavaju suočavanje s različitim fazama biološkog sazrijevanja i starenja, ali i socijalizacijskih utjecaja specifičnih za određenu dob. Jedno je istraživanje sugeriralo da stariji više koriste internet da bi istražili simptome (64\%), prognozu (68 \%) ili metode liječenja (62\%), dok preferiraju kontaktirati liječnika s pitanjima o lijekovima i nuspojavama (Medlock i sur., 2015). Ovo može biti specifičnost aktualnih generacija starijih koji se u kasnijoj dobi privikavaju na digitalizaciju, što odgovara utjecajima u vezi s povijesnim razdobljem. $\mathrm{K}$ tome, starije se osobe suočavaju sa zdravstvenim izazovima koji se razlikuju od osobe do osobe, poput specifičnih kroničnih somatskih bolesti ili psihičkih smetnji poput zdravstvene anksioznosti, što predstavlja nenormativne utjecaje. Dakle, osobe različite dobi birat će različito iz istih digitalnih okolina.

Proces pretraživanja. Osim što pretražuju o različitim temama, stariji možda pretražuju i na različit način. Tako stariji rjeđe preformuliraju svoje pretrage te osmišljavaju manje novih ključnih riječi za pretraživanje (Sanchiz, Chin, Chevalier, Amadieu i He, 2017) što je vjerojatno odraz opadanja kognitivnih funkcija. U jednom su istraživanju starije osobe pokušale uz pomoć interneta dijagnosticirati bolest na temelju opisa simptoma u vinjeti uz ,razmišljanje na glas" kako bi se dobio uvid u njihove kognitivne strategije (Luger, Houston i Suls, 2014). Pokazalo se da je većina sudionika koristila strategiju dijagnosticiranja prilikom koje prvo razmatraju, a potom odbacuju potencijalnu dijagnozu ako ona sadrži dodatne simptome koji nisu navedeni u vinjeti. Prilikom pretraživanja dvije trećine koristile su postojeće laičko medicinsko znanje, a polovica se oslanjala na vlastita ranija iskustva s bolesti. U drugom se istraživanju (Feufel i Stahl, 2012) pokazalo da su stariji skloniji pretraživati o zdravlju na način da potvrde vlastita vjerovanja (npr. upisuju u tražilicu: „cijepljenje je opasno“). To sugerira da postojeće reprezentacije bolesti usmjeravaju njihov proces pretraživanja.

Specifičnost procesa pretraživanja kod starijih jest da ono vjerojatno uključuje pretraživanje o većem broju simptoma koje istovremeno doživljavaju. Međutim, pokazalo se da stariji prilikom pokušaja dijagnosticiranja pretražuju o jednom po 
jednom simptomu umjesto o više simptoma zajedno (Luger i sur., 2014). Takav bi proces mogao rezultirati većim brojem zastrašujućih dijagnoza. Ako se tome doda i povećan doživljaj ranjivosti kod starijih, postoji rizik od ekscesivnog korištenja ove strategije s ciljem smanjenja rizika. Tako je pronađeno da sesije pretraživanja kod starijih traju dulje (Muse i sur., 2012). No, to može biti i odraz opadanja brzine različitih senzornih, kognitivnih i motoričkih funkcija ili slabijih vještina pretraživanja. Potrebna su dodatna istraživanja o tome kako se karakteristike pretraživanja o zdravlju na internetu mijenjaju ovisno o životnoj dobi i kakva je uloga postojećih reprezentacija bolesti u tom procesu.

\section{Pretraživanje o zdravlju na internetu kao strategija suočavanja s neugodnim emocijama}

Internet može biti i strategija suočavanja s neugodnim emocijama koje prate pojavu nekog simptoma, u vidu dobivanja socijalne podrške ili umirenja. Socijalne zdravstvene informacije, poput onih da i drugi doživljavaju slične simptome, mogu djelovati umirujuće (Croyle i Jemmott, 1991). Takve su informacije dostupne na internetskim forumima i grupama podrške (Harvey, Brown, Crawford, Macfarlane i McPherson, 2007). Tako je u jednom kvalitativnom istraživanju sudionica od 68 godina rekla da kada čita o iskustvima drugih o nekom zdravstvenim problemu, zaključi da „zapravo nije tako strašno, mnogi ljudi imaju taj problem“ (Huisman, Joye i Biltereyst, 2019). No, stariji navode da su informacije na internetu više usmjerene na mlađe osobe (Silver, 2015), što može otežati usporedbe. K tome, promjene koje prate starenje mogu dovesti do različitog iskazivanja simptoma $\mathrm{u}$ starijoj dobi i različitog djelovanja lijekova (Leventhal i Crouch, 1997; Levkoff, Cleary, Wetle i Besdine, 1988), pa sadržaji pisani za mlađe mogu starije navesti na pogrešan zaključak i možda ih uznemiriti. Zato ne iznenađuje da u jednoj studiji nitko od preko 250 osoba starijih od 65 godina nije sudjelovao u online-grupama podrške u vezi sa zdravljem (Honey, Waterworth i Aung, 2016).

\section{Utjecaj interneta na kognitivne reprezentacije bolesti}

Sadržaji o zdravlju na internetu mogu oblikovati reprezentacije bolesti, uključujući vjerovanja o tome koji su osjeti relevantni simptomi (npr. gubitak daha ili bol u kralježnici), što je uzrok simptoma (starost ili bolest), koje su posljedice ignoriranja simptoma (prolazna neugoda ili invaliditet), koji će oblici djelovanja biti učinkoviti u nošenju sa simptomom (zbrinjavanje kod kuće ili odlazak liječniku) te očekivanja o trajanju simptoma, bolesti i liječenja. U skladu s tim, utvrđeno je da pretraživanje rezultira novim znanjima i promjenom zdravstvenih ponašanja kod starijih (Medlock, Eslami, Askari, Sent i Abu-Hanna, 2013). Nova učenja o zdravlju s interneta utjecat će na interpretaciju budućih tjelesnih osjeta. No, kakvim točno znanjima pretraživanje rezultira? Stariji navode da su na internetu zdravstveni problemi opisani na zastrašujuć način (Silver, 2015), a pretraživanje često sugerira 
da su benigni simptomi rezultat ozbiljnih dijagnoza (White i Horvitz, 2009a) te da je pojedinac odgovoran za njihovo uočavanje, praćenje i tretiranje (Kata, 2010; Lupton, 2013). Kako navodi Lupton (2013), zdravstveni rizici smatraju se kontrolabilnima pod uvjetom da pojedinac koristi tehnologije za samomotrenje i samozbrinjavanje. To ima implikacije na atribute reprezentacije bolesti opisanog modela, poput identiteta, uzroka, posljedica i mogućnosti kontrole.

Digitalne zdravstvene informacije mogle bi imati drugačije efekte na reprezentacije bolesti osoba različite dobi. Kao prvo, stariji u trenutku pretraživanja obično posjeduju bogato vlastito iskustvo s bolesti. Za razliku od njih, pripadnici tzv. generacije digitalnih urođenika (engl. digital natives), koja ne poznaje život bez tehnologije, vjerojatno usvajaju digitalne zdravstvene informacije prije vlastitog iskustva s bolesti. Kao drugo, sukladno modelu zdravorazumske regulacije svjesnost o starenju također oblikuje reprezentacije bolesti pri čemu se osoba može vidjeti ranjivijom na neke bolesti (identitet, uzrok) ili može percipirati da će pogoršanje simptoma nastupiti brže (vremenska dimenzija), a liječenje biti manje uspješno (mogućnost kontrole). Zato bi trebalo istražiti kako se kod starijih nova znanja s interneta integriraju s postojećima i kakvim zdravstvenim ishodima rezultiraju.

$\mathrm{S}$ jedne strane, moguće je da informacije $\mathrm{s}$ interneta povećavaju zdravstvenu pismenost starijih i služe kao zaštitni čimbenik. Zaštitni čimbenici moderatori su rizika; oni predviđaju pozitivne, odnosno razvojno primjerene ishode u prisutnosti rizika ili nepovoljnih okolnosti (Werner, 2000). Tako pretraživanje o zdravlju na internetu olakšava razumijevanje simptoma, zdravstvenih smetnji i liječenja kod starijih osoba (Campbell, 2009). S druge strane, s obzirom na to da stariji doživljavaju više simptoma o kojima bi mogli pretraživati, da tražilice često sugeriraju ozbiljne dijagnoze, nove reprezentacije bolesti mogle bi rezultirati pretjeranim opažanjem tjelesnih osjeta i njihovom doživljaju kao prijetećem. Budući da postojeće iskustvo i uvjerenja usmjeravaju pretraživanje (Luger i sur., 2014), moguće je da odabir tome sukladnih informacija (Feufel i Stahl, 2012) učvršćuje postojeće reprezentacije bolesti, kakve god one bile.

\section{Procjene ishoda pretraživanja}

Procjena vjerodostojnosti sadržaja. Koliko stariji vjeruju zdravstvenim informacijama na internetu? Njihova manja upoznatost s tehnologijom može dovesti do skeptičnosti i nepovjerenja, ali i manjeg uočavanja potencijalnih rizika na internetu. Neka istraživanja sugeriraju da nema povezanosti između dobi i procjene vjerodostojnosti zdravstvenih informacija na internetu (Dart, 2008) ili da su stariji čak manje zabrinuti oko vjerodostojnosti informacija na internetu (Ybarra i Suman, 2006). Nasuprot teme, veći broj istraživanja sugerira da stariji imaju manje povjerenja u zdravstvene informacije na internetu, pri čemu stariji koji koriste internet imaju više povjerenja od starijih koji ga ne koriste (Chaudhuri, Le, White, 
Thompson i Demiris, 2013; Miller i Bell, 2012; Rideout, Neuman, Kitchman i Brodie, 2005; Zulman, Kirch, Zheng i An, 2011). Tako, među starijim korisnicima interneta njih $40 \%$ vjeruje da su zdravstvene informacije na internetu točne (Medlock i sur., 2015). Moguće je da korištenje dovodi do povjerenja, ali i da su oni koji zdravstvene informacije na internetu procjenjuju vjerodostojnima skloniji koristiti ga.

Zanimljivo, starije osobe koje nemaju povjerenja u informacije na internetu značajno ga rjeđe koriste od mladih osoba istih uvjerenja (Miller i Bell, 2012), što se u okviru modela autorica Leventhal i Crouch (2003) može objasniti povećanom percepcijom rizika od netočnih informacija kod starijih (Miller i Bell, 2012). Međutim, oni stariji koji se odluče na pretraživanje smatraju te informacije podjednako vjerodostojnima kao i mlađi. Također, čini se da ne pridaju puno pažnje procjeni vjerodostojnosti izvora zdravstvenih informacija prilikom pretraživanja (Luger i sur., 2014).

Uspješnost pretraživanja. Više je od polovice starijih na temelju pretraživanja o zadanim simptomima došlo do pogrešne dijagnoze, a to je češće bio slučaj za one koji su imali poteškoća sa snalaženjem na računalu (Luger i sur., 2014). No, čini se da stariji imaju više poteškoća u pronalaženju odgovora na zdravstvena pitanja na internetu čak i kada se kontrolira obrazovanje, zdravstvena pismenost i upotreba interneta (Agree, King, Castro, Wiley i Borzekowski, 2015). U drugom istraživanju nije utvrđena razlika u točnosti pronađenih informacija, no pokazalo se da starijima treba u prosjeku više vremena da ih pronađu (Sharit, Taha, Berkowsky i Czaja, 2016). Zanimljivo, stariji su pregledali manji broj stranica prije nego što bi došli do odgovora (Sharit i sur., 2016) što može sugerirati da su skloni pažljivijem pregledu sadržaja. Uspješnost pretraživanja na internetu ovisi i o složenosti zadatka, pa su tako stariji u laganim i srednje teškim zadacima bili podjednako uspješni kao i mlađi, ali su u težim zadacima bili manje uspješni (Sanchiz i sur., 2017). No, njihovo bogatije znanje o zdravstvenim pitanjima, $u$ odnosu na znanje mlađih, pomagalo im je $u$ pretraživanju (Sanchiz i sur., 2017).

Ponašajne, kognitivne i emocionalne posljedice. Pretraživanje o zdravlju na internetu može rezultirati ponašajnim, kognitivnim i emocionalnim posljedicama. Tako $34 \%$ starijih osoba na temelju zdravstvenih informacija na internetu barem ponekad ode liječniku, a $51 \%$ napravi neke životne promjene. Njih $41 \%$ barem je ponekad posumnjalo u uspostavljenu dijagnozu, a $36 \%$ u tretman, dok je $58 \%$ osjećalo da nakon pretraživanja zna više. Kada govorimo o emocionalnim posljedicama pretraživanja, $36 \%$ starijih postalo je anksiozno, $54 \%$ umireno, a 34 $\%$ zbunjeno na temelju pronađenih sadržaja (Medlock i sur., 2013). Slično je utvrđeno i za mlađe odrasle osobe (White i Horvitz, 2009b). Zanimljivo, i umirenost i uznemirenost češće se javljaju kod onih starijih osoba koje koriste internet kao izvor zdravstvenih informacija (Medlock i sur., 2013). Moguće objašnjenje tog nalaza leži u vrlo maloj vjerojatnosti da osoba ne pronađe traženi podatak, bio on zastrašujući ili ne, što govori o još jednoj specifičnosti ove strategije suočavanja. 
Konačno, kakvom stariji procjenjuju učinkovitost pretraživanja o zdravlju na internetu kao strategije suočavanja? Za sada se pokazuje da oni koji se njime koriste vjeruju sadržajima na internetu, usvajaju nova znanja i mijenjaju zdravstvena ponašanja. No, nekada imaju poteškoće u pronalaženju sadržaja te ih sadržaj koji pronađu zna uznemiriti. Ako je ova strategija učinkovita za jedan cilj - suočavanje sa zdravstvenom prijetnjom, a djelomično neučinkovita za drugi - suočavanje sa strahom, kakve to ima posljedice na njezino korištenje? Neki autori smatraju da taktika „bolje spriječiti, nego liječiti“ potiče pretjerano pretraživanje unatoč anksioznosti koju ono izaziva (Brown, Skelly i Chew- Graham, 2019).

\section{Kiberohondrija kod starijih}

Pretjerano pretraživanje o simptomima na internetu praćeno porastom anksioznosti nazvano je kiberohondrija (Starcevic i Berle, 2013). Glavne su dimenzije konstrukta kiberohondrije: kompulzivnost, distres, ekscesivnost, traženje umirenja/razuvjeravanja i nepovjerenje u medicinsko osoblje (McElroy i Shevlin, 2014). Iako nismo pronašli istraživanja kiberohondrije specifično kod starijih, nekoliko je istraživanja uključivalo sudionike različite dobi, pa je moguće napraviti dobne usporedbe. Većina istraživanja sugerira da su osobe različite dobi podjednako podložne kiberohondriji (Barke, Bleichhardt, Rief, i Doering, 2016; Batigun, Gor, Komurcu i Ertuk, 2018; Fergus i Spada, 2017). Sukladno tome, pokazalo se da dob nije povezana $\mathrm{s}$ učestalošću pretraživanja, ni distresom i anksioznošću nakon pretraživanja (Muse i sur., 2012).

Nasuprot tome, neka istraživanja sugeriraju da bi dob mogla igrati ulogu u pojavi anksioznosti uslijed pretraživanja, iako nije sasvim jasno kakvu. Tako se pokazalo da je dob negativan prediktor anksioznosti za vrijeme i nakon pretraživanja o simptomima (Doherty-Torstrick, Walton i Fallon, 2016) te da starije osobe rjeđe na internet odlaze s ciljem samodijagnosticiranja (Fox i Duggan, 2013; Ybarra i Suman, 2006). To bi sugeriralo da su stariji manje podložni kiberohondriji. No, recentna je metaanalitička studija (McMullan, Berle, Arnáez i Starcevic, 2018) pokazala da je dob izvor heterogenosti u povezanosti između kiberohondrije i zdravstvene anksioznosti od studije do studije. Pri tome je povezanost među ovim konstruktima snažnija u starijoj populaciji sudionika što su autori interpretirali na način da kod mlađih zdravstveno anksioznih osoba pretraživanje češće rezultira umirenjem. To bi, suprotno prethodnom nalazu, sugeriralo da je pretraživanje osobito rizično upravo za osobe starije životne dobi, ali samo one koje već jesu zdravstveno anksioznije. Možda na način da postojeće kognitivne reprezentacije bolesti tih osoba usmjeravaju njihove pretrage na zastrašujuće sadržaje.

Dobne razlike mogu biti i kvalitativne naravi, a ne samo u intenzitetu ili prevalenciji patologije. Prvo, okidači anksioznosti prilikom pretraživanja mogu biti drugačiji u starijoj populaciji. Primjerice, stariji se vide osjetljivijima na pojedine bolesti, ali čak i manje osjetljivima na neke druge, poput raka dojke (Leventhal i 
Crouch, 1997), što znači da će ih uznemiriti drugačiji sadržaj u odnosu na mlađe. Osim toga, stariji navode i da su informacije na internetu usmjerene na mlađe osobe, što je prepoznato kao okidač anksioznosti prilikom pretraživanja na internetu specifičan za starije osobe (Silver, 2015).

Drugo, kiberohondrija može imati drugačiju manifestaciju u starijoj populaciji. Pokazalo se da je dob pozitivno povezana samo s jednom dimenzijom kiberohondrije - nepovjerenjem u zdravstvene djelatnike (Barke i sur., 2016). Istovremeno, neki autori smatraju da upravo ova dimenzija nije dio konstrukta kiberohondrije zbog slabe povezanosti s ostalim dimenzijama u općoj populaciji (npr. Fergus i Spada, 2018). Međutim, nepovjerenje u medicinske djelatnike moglo bi biti vrlo netipično u populaciji starijih, pa je možda relevantan aspekt kiberohondrije u ovoj populaciji.

Zaključno, do sada provedena istraživanja o pretraživanju o zdravlju na internetu kod starijih mogu se smisleno integrirati u model zdravorazumske regulacije Leventhal i Crouch (1997), koji nudi i smjernice za buduća istraživanja. Iako je ovaj model razvijen u okviru zdravstvene psihologije i objašnjava zdravstvena ponašanja i ishode, može objasniti i pojavu nepotrebne zabrinutosti za zdravlje oko benignih tjelesnih osjeta. U tom smislu, postoje teorijske i empirijske indikacije da bi pretraživanje o zdravlju na internetu moglo biti rizično ponašanje koje na specifičan način djeluje na starije, čineći neke od njih ranjivijima na pojavu pretjerane zabrinutosti za zdravlje.

\section{Kritički osvrt na dosadašnja istraživanja}

Opisana istraživanja imaju nekoliko nedostataka. Prvo, velik broj istraživanja o pretraživanju uključivao je mlađe starije osobe (do 75 godina), što znači da znamo vrlo malo o starijim starim osobama (76 i više godina). U istraživanjima kiberohondrije sudionici su uglavnom bile osobe do oko 65 godina, pa ona praktički i ne uključuju populaciju starijih. Drugo, u velikom broju istraživanja korišteni su kvantitativni i presječni nacrti. No, longitudinalna istraživanja dala bi jasniji uvid u mehanizam djelovanja ovoga rizičnog čimbenika. Kvalitativna istraživanja nužna su jer u različitoj dobi anksioznost izazivaju različiti sadržaji, u njihovoj podlozi mogu biti različiti mehanizmi te se osobe različite dobi s njom mogu nositi na različite načine. I treće, populacija starijih vrlo je heterogena skupina, pa neki smatraju da starije treba klasificirati u različite skupine, i to ne samo po dobi, spolu i obrazovanju već i po funkcionalnoj, socijalnoj, i kognitivnoj dobi (Fischer, David, Crotty, Dierks i Safran, 2014). Logično je pretpostaviti da pretraživanje o zdravlju na internetu ima specifične efekte na osobe slabijeg zdravlja ili oslabljenih kognitivnih funkcija.

\section{Smjernice za buduća istraživanja}

S obzirom na to da internet nudi brz pristup golemoj količini zdravstvenih informacija, istraživanje posljedica njihova konzumiranja kod starijih daje 
zanimljive mogućnosti provjere različitih elemenata modela Leventhal i Crouch (1997). Takva istraživanja mogu pridonijeti boljem razumijevanju uloge interneta kako u očuvanju dobrog zdravlja, tako i u razvoju psihopatologije. Primjerice, stariji se prema nalazima nekih istraživanja percipiraju čak i manje ranjivima na neke bolesti (Gerend, Aiken, West i Erchull, 2004), možda jer su dugo godina živjeli bez tih bolesti što mijenja njihovu percepciju rizika. S obzirom na to da stariji objektivno jesu ranjiviji na određene bolesti, poput primjerice aktualnu bolest uzorkovanu koronravirusom, o kojoj se također danas najviše informiramo putem interneta, važno je razumjeti kako stariji te informacije konzumiraju te kako one utječu na njihovu percepciju ranjivosti, a time i provođenje zaštitnih ponašanja. U tom smislu istraživanja mogu pokazati na koji je način najbolje prenijeti poruku o povećanom riziku. Nadalje, buduća istraživanja trebala bi se usmjeriti i na karakteristike pretraživanja kod starijih te interakciju postojećih kognitivnih reprezentacija bolesti i sadržaja s interneta, osobito njihovu ulogu u pojavi nepotrebne zabrinutosti za zdravlje.

U okviru pristupa cjeloživotnog razvoja važno je istraživačko pitanje identifikacija različitih razvojnih putanja u području zdravlja (Spiro III, 2007), pa onda i specifičnije u vezi suočavanja sa zdravstvenim prijetnjama. Primjerice, moguće je da neke starije osobe u kontaktu sa zastrašujućim zdravstvenim informacijama na internetu počinju izbjegavati internet zbog uznemirenosti, neke možda samo povremeno konzultiraju internet ili kombiniraju različite izvore zdravstvenih informacija, a neke postupno pretražuju sve više i postaju sve zabrinutije za svoje zdravlje. Svaka putanja može rezultirati i pozitivnim i negativnim ishodima (Spiro III, 2007). Primjerice, pretjerano pretraživanje možda ima negativne posljedice na psihičko, a pozitivne posljedice na neke aspekte somatskog zdravlja.

Pored toga, vjerujemo da je važno istražiti kako se interakcija između liječnika i pacijenta mijenja uslijed pacijentova pretraživanja o zdravlju na internetu. Danas pacijenti, osobito oni mlađi, dolaze u liječnikovu ordinaciju ,naoružani“ znanjem s interneta. S druge strane, liječnici nude dodatne zdravstvene informacije koje također imaju implikacije na kognitivne reprezentacije bolesti, a koje mogu biti u konfliktu s onima stečenima na internetu. Starije osobe mogu biti nespremne razgovarati o sadržajima s interneta s liječnikom (Silver, 2015), jer su primjerice naviknute na tradicionalne uloge liječnika i pacijenta s većim raskorakom u znanju i moći. Stariji navode da su od rane dobi internalizirali da su liječnici osobe od autoriteta, ali su istovremeno svjesni da je odnos između liječnika i pacijenta danas drugačiji (Huisman i sur., 2019). Tako informacije s interneta oprezno uvode u razgovor ili ih pak i ne spominju, a na kraju na temelju svih pruženih informacija samostalno donesu odluku (Huisman i sur., 2019). Liječnici i sami mogu biti manje ili više skloni upotrebi modernih tehnologija. Sličnost liječnikovih i pacijentovih stavova o korištenju interneta u zdravstvene svrhe mogla bi utjecati na njihov odnos, odluke o liječenju i ishode liječenja. 


\section{Praktične implikacije}

Razumijevanje rizičnih čimbenika koji pridonose patološkoj zdravstvenoj anksioznosti može pomoći u prevenciji i tretmanu ovog, kod starijih, vrlo prevalentnog poremećaja. Primjerice, edukacija o učinkovitom pretraživanju o zdravlju na internetu mogla bi pomoći starijim osobama da odaberu kvalitetne sadržaje (Xie i Bugg, 2009) te uspješno razlikuju simptome bolesti od promjena koje prirodno prate starenje. U tom slučaju pretraživanje o zdravlju može biti zaštitni čimbenik za njihovo tjelesno zdravlje. Izrada internetskih sadržaja o zdravlju specifično namijenjenima starijima (Barbara i sur., 2016) može im pomoći u lakšem snalaženju. S obzirom na to da zdravstveni sadržaji na internetu mogu biti niske kvalitete i zastrašujući, važno je starije potaknuti na razgovor s liječnikom. I na kraju, tretman zdravstvene anksioznosti i kiberohondrije kod starijih treba uzeti u obzir specifičnosti ove populacije; poteškoće na koje nailaze prilikom pretraživanja, okolnosti koje izazivaju zabrinutost te vjerovanja o vlastitu zdravlju koja ju održavaju.

\section{Zaključak}

Broj osoba starijih od 60. godina do 2050. udvostručit će se u odnosu na njihov broj u 2017. godini i dosegnuti brojku od 2.1 milijarde (United Nations, Department of Economic and Social Affairs, 2017). Istraživanja pokazuju da starije osobe sve više koriste internet te da često pretražuju upravo o zdravlju. Internet je jedinstven globalan fenomen kojemu svatko pristupa na drugačiji način uslijed čega je i iskustvo korištenja od osobe do osobe drugačije, kao i znanja koja se usvajaju i koriste u svakodnevnici. Starije osobe vrlo su zanimljiva demografska skupina jer su koncepte o zdravlju, bolesti i liječenju usvojile davno, a sada su prisiljene snalaziti se u digitaliziranom svijetu koji izmiče autoritetu i jednoznačnoj istini. Mnogi se od njih nose $\mathrm{s}$ različitim kognitivnim smetnjama koje dodatno otežavaju snalaženje i prilagodbu. Njihova interakcija $\mathrm{s}$ digitalnim zdravstvenim sadržajem važna je istraživačka tema budućnosti. Stoga je nužno postojeće nalaze integrirati u teorijske modele, širiti ih i razvijati. Model zdravorazumske samoregulacije pruža mogućnost takve integracije postojećih nalaza i usmjeravanja budućih istraživanja.

\section{Literatura}

Agree, E. M., King, A. C., Castro, C. M., Wiley, A. i Borzekowski, D. L. (2015). “It's got to be on this page": Age and cognitive style in a study of online health information seeking. Journal of Medical Internet Research, 17(3), 1-10. 
Alsaiari, A., Joury, A., Aljuaid, M., Wazzan, M. i Pines, J. M. (2016). The content and quality of health information on the internet for patients and families on adult kidney cancer. Journal of Cancer Education, 32(4), 878-884.

American Psychiatric Association. (2013). Diagnostic and statistical manual of mental disorders (DSM-5®). Washington, DC: American Psychiatric Pub.

Asmundson, G. J. G., Taylor, S. i Cox, B. J. (2001). Health anxiety: Clinical and research perspectives on hypochondriasis and related conditions. Cichester, New York: John Wiley \& Sons, LTD.

Bagarić, B. i Jokić-Begić, N. (2019). Kiberohondrija-zdravstvena anksioznost uvjetovana pretraživanjem interneta. Socijalna psihijatrija, 47(1), 28-50.

Baker, D. W., Gazmararian, J. A., Sudano, J. i Patterson, M. (2000). The association between age and health literacy among elderly persons. The Journals of Gerontology Series B: Psychological Sciences and Social Sciences, 55(6), S368-S374.

Baltes, P. B. (1987). Theoretical propositions of life-span developmental psychology: On the dynamics between growth and decline. Developmental Psychology, 23(5), 611-626.

Barbara, A. M., Dobbins, M., Haynes, R. B., Iorio, A., Lavis, J. N., Raina, P. i Levinson, A. J. (2016). The McMaster Optimal Aging Portal: Usability evaluation of a unique evidence-based health information website. JMIR Human Factors, 3(1), 1-19.

Barke, A., Bleichhardt, G., Rief, W. i Doering, B. K. (2016). The Cyberchondria Severity Scale (CSS): German validation and development of a short form. International Journal of Behavioral Medicine, 23(5), 595-605.

Bass, S. B. (2003). How will Internet use affect the patient? A review of computer network and closed Internet-based system studies and the implications in understanding how the use of the Internet affects patient populations. Journal of Health Psychology, 8, 25-38.

Batigun, A. D., Gor, N., Komurcu, B. i Erturk, I. S. (2018). Cyberchondria Scale (CS): Development, validity and reliability study. Dusunen Adam-Journal of Psychiatry and Neurological Sciences, 31(2), 148-162.

Baumgartner, S. E. i Hartmann, T. (2011). The role of health anxiety in online health information search. Cyberpsychology, Behavior, and Social Networking, 14(10), 613618.

Bessière, K., Pressman, S., Kiesler, S. i Kraut, R. (2010). Effects of internet use on health and depression: A longitudinal study. Journal of Medical Internet Research, 12(1), e6.

Bleichhardt, G. i Hiller, W. (2007). Hypochondriasis and health anxiety in the German population. British Journal of Health Psychology, 12(4), 511-523. http://dx.doi.org/ 10.1348/135910706X146034

Borzekowski, D. L. i Rickert, V. I. (2001). Adolescents, the internet, and health: Issues of access and content. Journal of Applied Developmental Psychology, 22(1), 49-59.

Bradley, M. C. i Hughes, C. M. (2013). Issues in aging, adherence, and health-behavior change. U: L. R. Martin i M. R. DiMatteo (Ur.), The Oxford handbook of health 
communication, behavior change, and treatment adherence (str. 432-452). New York: Oxford University Press.

Brown, R. J., Skelly, N. i Chew-Graham, C. A. (2019). Online health research and health anxiety: A systematic review and conceptual integration. Clinical Psychology: Science and Practice, e12299.

Buhi, E. R., Daley, E. M., Fuhrmann, H. J. i Smith, S. A. (2009). An observational study of how young people search for online sexual health information. Journal of American College Health, 58(2), 101-111.

Bujnowska-Fedak, M. M., Waligóra, J. i Mastalerz-Migas, A. (2019). The internet as a source of health information and services. U: M. Pokorski (Ur.), Advances in experimental medicine and biology (str. 1-16). New York, NY: Springer.

Campbell, R. J. (2009). Internet-based health information seeking among low-income, minority seniors living in urban residential centers. Home Health Care Management \& Practice, 21(3), 195-202.

Chang, S. J. i Im, E. O. (2014). A path analysis of Internet health information seeking behaviors among older adults. Geriatric Nursing, 35(2), 137-141.

Chaudhuri, M. S., Le, M. T., White, M. C., Thompson, H. i Demiris, G. (2013). Examining health information-seeking behaviors of older adults. Computers, Informatics, Nursing: CIN, 31(11), 547-553.

Cicchetti, D. i Cohen, D. J. (Eds). (2006). Developmental psychopathology, Volume 1: Theory and method ( $2^{\text {nd }}$ ed). New Jersey: John Wiley \& Sons.

Cotten, S. R. i Gupta, S. S. (2004). Characteristics of online and offline health information seekers and factors that discriminate between them. Social Science \& Medicine, 59(9), 1795-1806.

Croyle R. T. i Jemmott, J. B. (1991). Psychological reactions to risk factor testing. U: J. A. Skelton i R. T. Croyle (Ur.), Mental representation in health and illness. Contributions to psychology and medicine (str. 85-107). New York, NY: Springer.

Dart, J. (2008). The internet as a source of health information in three disparate communities. Australian Health Review, 32(3), 559-569.

Doherty-Torstrick, E. R., Walton, K. E. i Fallon, B. A. (2016). Cyberchondria: Parsing health anxiety from online behavior. Psychosomatics, 57(4), 390-400.

El-Gabalawy, R., Mackenzie, C. S., Thibodeau, M. A., Asmundson, G. J. G. i Sareen, J. (2013). Health anxiety disorders in older adults: Conceptualizing complex conditions in late life. Clinical Psychology Review, 33(8), 1096-1105.

European Commission. (2015). Flash Eurobarometer 404 (European Citizens' Digital Health Literacy). TNS Political \& Social [producer]. GESIS Data Archive, Cologne. ZA 5948 Data file Version 1.0.0, doi:10.4232/1.12194

Fergus, T. A. i Spada, M. M. (2017). Cyberchondria: Examining relations with problematic Internet use and metacognitive beliefs. Clinical Psychology \& Psychotherapy, 24(6), 1322-1330. 
Fergus, T. A. i Spada, M. M. (2018). Moving toward a metacognitive conceptualization of cyberchondria: Examining the contribution of metacognitive beliefs, beliefs about rituals, and stop signals. Journal of Anxiety Disorders, 60, 11-19.

Feufel, M. A. i Stahl, S. F. (2012). What do web-use skill differences imply for online health information searches? Journal of Medical Internet Research, 14(3), e87.

Fischer, S. H., David, D., Crotty, B. H., Dierks, M. i Safran, C. (2014). Acceptance and use of health information technology by community-dwelling elders. International Journal of Medical Informatics, 83(9), 624-635.

Flynn, K. E., Smith, M. A. i Freese, J. (2006). When do older adults turn to the internet for health information? Findings from the Wisconsin Longitudinal Study. Journal of General Internal Medicine, 21(12), 1295-1301.

Fox, S. (2000). The online health care revolution: How the web helps Americans take better care of themselves. A Pew Internet and American Life Project Online Report. http://www. pewinternet. org/reports/pdfs/PIP_Health_Report.pdf

Fox, S. (2011). Health topics. Pew Internet \& American Life Project, 33. http://pewinternet.org/Reports/2011/HealthTopics.aspx

Fox, S. i Duggan, M. (2013). Health online 2013. Washington, DC: Pew Internet \& American Life Project, 1.

Fox, S. i Jones, S. (2009). The social life of health information. Washington: Pew Internet \& American Life Project.

Fox, S. i Rainie, L. (2002). Vital decisions: How internet users decide what information to trust when they or their loved ones are sick: Plus a guide from the medical library association about smart health-search strategies and good web sites. Pew Internet \& American Life Project.

Gallagher, S. i Doherty, D. T. (2009). Searching for health information online: Characteristics of online health seekers. Journal of Evidence-Based Medicine, 2(2), 99-106.

Gerend, M. A., Aiken, L. S., West, S. G. i Erchull, M. J. (2004). Beyond medical risk: Investigating the psychological factors underlying women's perceptions of susceptibility to breast cancer, heart disease, and osteoporosis. Health Psychology, 23(3), 247-258.

Ghubach, R., El-Rufaie, O., Zoubeidi, T., Sabri, S., Yousif, S. i Moselhy, H. F. (2010). Subjective life satisfaction and mental disorders among older adults in UAE in general population. International Journal of Geriatric Psychiatry, 25(5), 458-465. http://dx.doi.org/ 10.1002/gps.2360

Grohol, J. M., Slimowicz, J. i Granda, R. (2013). The quality of mental health information commonly searched for on the Internet. Cyberpsychology, Behavior, and Social Networking, 17(4), 216-221.

Harvey, K. J., Brown, B., Crawford, P., Macfarlane, A. i McPherson, A. (2007). 'Am I normal?' Teenagers, sexual health and the internet. Social Science \& Medicine, 65(4), 771-781. 
Hirsch, M., Aggarwal, S., Barker, C., Davis, C. J. i Duffy, J. M. (2017). Googling endometriosis: A systematic review of information available on the Internet. American Journal of Obstetrics and Gynaecology, 216(5), 451-458.

Honey, M. L., Waterworth, S. i Aung, H. (2016). Older consumers' readiness for e-health in New Zealand. Nursing Informatics, 255, 178-182. doi:10.3233/978-1-61499-658-3-178

Huisman, M., Joye, S. i Biltereyst, D. (2019). Searching for health: Doctor Google and the shifting dynamics of the middle-aged and older adult patient-physician relationship and interaction. Journal of Aging and Health, 1-21. doi:10.1177/0898264319873809

Hunt, S., Wisocki, P. i Yanko, J. (2003). Worry and use of coping strategies among older and younger adults. Journal of Anxiety Disorders, 17(5), 547-560.

Jacobs, W., Amuta, A. O. i Jeon, K. C. (2017). Health information seeking in the digital age: An analysis of health information seeking behavior among US adults. Cogent Social Sciences, 3(1), 1302785. https://doi.org/10.1080/23311886.2017.1302785

Kata, A. (2010). A postmodern Pandora's box: Anti-vaccination misinformation on the Internet. Vaccine, 28(7), 1709-1716.

Kazdin, A. E., Kraemer, H. C., Kessler, R. C., Kupfer, D. J. i Offord, D. R. (1997). Contributions of risk-factor research to developmental psychopathology. Clinical Psychology Review, 17(4), 375-406.

Kontos, E., Blake, K. D., Chou, W. Y. S. i Prestin, A. (2014). Predictors of eHealth usage: Insights on the digital divide from the Health Information National Trends Survey 2012. Journal of Medical Internet Research, 16(7), 1-16.

Lambert, S. D. i Loiselle, C. G. (2007). Health information-seeking behavior. Qualitative Health Research, 17(8), 1006-1019.

Lee, Y. J., Boden-Albala, B., Larson, E., Wilcox, A. i Bakken, S. (2014). Online health information seeking behaviors of Hispanics in New York City: A community-based cross-sectional study. Journal of Medical Internet Research, 16(7), 1-13.

Leventhal, H., Brissette, I. i Leventhal, E. A. (2003). The common-sense model of selfregulation of health and illness. U: L. D. Cameron i H. Leventhal (Ur.), The selfregulation of helath and illness behavior (str. 42-60). London: Routledge Taylor and Francis Group.

Leventhal, E. A. i Crouch, M. (1997). Are there differences in perceptions of illness across the lifespan? U: K. J. Petrie i J. A. Weinnman (Ur.), Perceptions of Health \& Illnes (str. 91-116). Amsterdam: Psychology Press.

Levkoff, S. E., Cleary, P. D., Wetle, T. i Besdine, R. W. (1988). Illness behavior in the aged: Implications for clinicians. Journal of the American Geriatrics Society, 36(7), 622-629.

Lewis, T. (2006). Seeking health information on the internet: Lifestyle choice or bad attack of cyberchondria? Media, Culture \& Society, 28(4), 521-539.

Longo, D. R. (2005). Understanding health information, communication, and information seeking of patients and consumers: A comprehensive and integrated model. Health Expectations, 8(3), 189-194. 
Longtin, Y., Sax, H., Leape, L. L., Sheridan, S. E., Donaldson, L. i Pittet, D. (2010). Patient participation: Current knowledge and applicability to patient safety. Mayo Clinic Proceedings, 85(1), 53-62.

Lucock, M. P. i Morley, S. (1996). The health anxiety questionnaire. British Journal of Health Psychology, 1(2), 137-150.

Luger, T. M., Houston, T. K. i Suls, J. (2014). Older adult experience of online diagnosis: Results from a scenario-based think-aloud protocol. Journal of Medical Internet Research, 16(1), 1-12.

Lupton, D. (2013). Digitized health promotion: Personal responsibility for health in the Web 2.0 Era. Sydney Health \& Society Group Working Paper No. 5. Sydney: Sydney Health \& Society Group.

Martin, R., Rothrock, N., Leventhal, H. i Leventhal, E. (2003). Common sense models of illness: Implications for symptom perception and health-related behaviors. U: J. Suls i K. A. Wallston (Ur.), Social psychological foundations of health and illness (str. 199225). Malden, MA: Blackwell Publishing.

McElroy, E. i Shevlin, M. (2014). The development and initial validation of the Cyberchondria severity scale (CSS). Journal of Anxiety Disorders, 28(2), 259-265.

Mcinnes, N. i Haglund, B. J. (2011). Readability of online health information: Implications for health literacy. Informatics for Health and Social Care, 36(4), 173-189.

McMullan, R. D., Berle, D., Arnáez, S. i Starcevic, V. (2018). The relationships between health anxiety, online health information seeking, and cyberchondria: Systematic review and meta-analysis. Journal of Affective Disorders, 245, 270-278.

Medlock, S., Eslami, S., Askari, M., Arts, D. L., Sent, D., de Rooij, S. E. i Abu-Hanna, A. (2015). Health information-seeking behavior of seniors who use the internet: A survey. Journal of Medical Internet Research, 17(1), 1-11.

Medlock, S., Eslami, S., Askari, M., Sent, D. i Abu-Hanna, A. (2013). The consequences of seniors seeking health information using the internet and other sources. Studies in Health Technology and Informatics, 192, 457-460.

Miller, L. M. S. i Bell, R. A. (2012). Online health information seeking: The influence of age, information trustworthiness, and search challenges. Journal of Aging and Health, 24(3), 525-541.

Moreland, J., French, T. L. i Cumming, G. P. (2015). The prevalence of online health information seeking among patients in Scotland: A cross-sectional exploratory study. JMIR Research Protocols, 4(3), 1-11.

Muse, K., McManus, F., Leung, C., Meghreblian, B. i Williams, J. M. G. (2012). Cyberchondriasis: Fact or fiction? A preliminary examination of the relationship between health anxiety and searching for health information on the Internet. Journal of Anxiety Disorders, 26(1), 189-196. 
NTIA. (National Telecommunications and Information Administration). (2011). Digital nation; expanding Internet usage. Preuzeto s http://www.ntia.doc.gov/files/ntia/ publications/ntia_internet_use_report_february_2011.pdf

Poon, C. Y. i Knight, B. G. (2009). Influence of sad mood and old age schema on older adults' attention to physical symptoms. Journals of Gerontology Series B: Psychological Sciences and Social Sciences, 64(1), 41-44.

Prestin, A., Vieux, S. N. i Chou, W. Y. S. (2015). Is online health activity alive and well or flatlining? Findings from 10 years of the Health Information National Trends Survey. Journal of Health Communication, 20(7), 790-798.

Prohaska, T. R., Leventhal, E. A., Leventhal, H. i Keller, M. L. (1985). Health practices and illness cognition in young, middle aged, and elderly adults. Journal of Gerontology, 40(5), 569-578.

Rideout, V., Neuman, T., Kitchman, M. i Brodie, M. (2005). E-Health and the elderly: How seniors use the Internet for health information. Menlo Park, CA: Kaiser Family Foundation.

Rutter, M. (1988). Epidemiological approaches to developmental psychopathology. Archives of General Psychiatry, 45(5), 486-495.

Sanchiz, M., Chin, J., Chevalier, A., Fu, W. T., Amadieu, F. i He, J. (2017). Searching for information on the web: Impact of cognitive aging, prior domain knowledge and complexity of the search problems. Information Processing \& Management, 53(1), 281294.

Sarkisian, C. A., Lee-Henderson, M. H. i Mangione, C. M. (2003). Do depressed older adults who attribute depression to "old age" believe it is important to seek care? Journal of General Internal Medicine, 18(12), 1001-1005.

Scarella, T. M., Laferton, J. A., Ahern, D. K., Fallon, B. A. i Barsky, A. (2016). The relationship of hypochondriasis to anxiety, depressive, and somatoform disorders. Psychosomatics, 57(2), 200-207.

Sharit, J., Taha, J., Berkowsky, R. W. i Czaja, S. J. (2016). Seeking and resolving complex online health information: Age differences in the role of cognitive abilities. Proceedings of the human factors and ergonomics society annual meeting, 60(1), 1-5.

Silver, M. P. (2015). Patient perspectives on online health information and communication with doctors: A qualitative study of patients 50 years old and over. Journal of Medical Internet Research, 17(1), 1-15.

Singh, K. i Brown, R. J. (2014). Health-related Internet habits and health anxiety in university students. Anxiety, Stress, \& Coping, 27(5), 542-554.

Singh, K. i Brown, R. J. (2016). From headache to tumour: An examination of health anxiety, health-related Internet use and 'query escalation'. Journal of Health Psychology, 21(9), 2008-2020. 
Spiro III, A. (2007). The relevance of a lifespan developmental approach to health. U: C. M. Aldwin, C. L. Park i A. Spiro III (Ur.), Handbook of health psychology and aging (str. 75-95). New York: Guilford Press.

Starcevic, V. i Berle, D. (2013). Cyberchondria: Towards a better understanding of excessive health-related Internet use. Expert Review of Neurotherapeutics, 13(2), 205-213.

Stronge, A. J., Rogers, W. A. i Fisk, A. D. (2006). Web-based information search and retrieval: Effects of strategy use and age on search success. Human Factors, 48(3), 434-446.

Taha, J., Sharit, J. i Czaja, S. (2009). Use of and satisfaction with sources of health information among older Internet users and nonusers. The Gerontologist, 49(5), 663-673.

Tan, S. S. L. i Goonawardene, N. (2017). Internet health information seeking and the patientphysician relationship: A systematic review. Journal of Medical Internet Research, 19(1), e9.

Tardy, R. W. i Hale, C. L. (1998). Getting "plugged in": A network analysis of healthinformation seeking among "stay- at- home moms". Communications Monographs, 65(4), 336-357.

te Poel, F., Baumgartner, S. E., Hartmann, T. i Tanis, M. (2016). The curious case of cyberchondria: A longitudinal study on the reciprocal relationship between health anxiety and online health information seeking. Journal of Anxiety Disorders, 43, 32-40.

Thistlethwaite, J. (2005) Patient partnership and shared decision making: Involving patients in management decisions. Health Issues, 83, 22-25.

United Nations. Department of Economic and Social Affairs. (2017). World Population Prospects: The 2017 Revision. Preuzeto s https://www.un.org/development/desa/ publications/world-population-prospects-the-2017-revision.html

Wagner, N., Hassanein, K. i Head, M. (2010). Computer use by older adults: A multidisciplinary review. Computers in Human Behavior, 26(5), 870-882.

Ward, B. W. i Schiller, J. S. (2013). Peer reviewed - Prevalence of multiple chronic conditions among US adults: Estimates from the National Health Interview Survey, 2010. Preventing Chronic Disease, 10, 1-15.

Werner, E. E. (2000). Protective factors and individual resilience. U: J. P. Shonkoff i S. J. Meisels (Ur.), Handbook of early childhood intervention (str. 115-132). New York: Cambridge University Press.

White, R. W. i Horvitz, E. (2009a). Cyberchondria: Studies of the escalation of medical concerns in web search. ACM Transactions on Information Systems (TOIS), 27(4), 1-37.

White, R. W. i Horvitz, E. (2009b). Experiences with web search on medical concerns and self diagnosis. AMIA annual symposium proceedings, 696-700.

Wurm, S., Warner, L. M., Ziegelmann, J. P., Wolff, J. K. i Schüz, B. (2013). How do negative self-perceptions of aging become a self-fulfilling prophecy? Psychology and Aging, 28(4), 1-10. 
Xie, B. i Bugg, J. M. (2009). Public library computer training for older adults to access highquality Internet health information. Library \& Information Science Research, 31(3), $155-162$.

Ybarra, M. i Suman, M. (2006). Reasons, assessments and actions taken: Sex and age differences in uses of Internet health information. Health Education Research, 23(3), 512-521.

Ziebland, S. U. E. i Wyke, S. (2012). Health and illness in a connected world: How might sharing experiences on the internet affect people's health? The Milbank Quarterly, 90(2), 219-249.

Zulman, D. M., Kirch, M., Zheng, K. i An, L. C. (2011). Trust in the internet as a health resource among older adults: Analysis of data from a nationally representative survey. Journal of Medical Internet Research, 13(1), 1-10.

\title{
Health Information Seeking on the Internet - Implications for Health Anxiety in the Elderly
}

\begin{abstract}
Health information seeking on the Internet has become widespread. Since the elderly experience more health issues, they might become more frequent users of digital health content. But, since their computer skills are less advanced and since they are not used to the role of the ,empowered patient", researching their symptoms online might result in excessive anxiety. Research suggests that health information seeking might be a risk factor for pathological health anxiety, yet it may have a specific effect on the elderly. Studies on health information seeking in older adults are sparse and mostly conducted without a clear theoretical framework which complicates meaningful interpretation and integration of their findings. Therefore, the aim of this review paper is to propose such theoretical framework; Leventhal's Common-sense model of self-regulation, and to review findings of previous studies in the area integrating them in the proposed model. According to this model, ageing and age-related changes in the self, affect health-related cognitions and behaviours. Health information seeking may be conceptualized as a coping response to both health threat and emotional discomfort, which has consequences on illness representations (identity, cause, consequences, control, and timeline), health behaviours and outcomes. Special emphasis was placed to a way in which health information seeking online can result in health anxiety according to the proposed model. Finally, avenues for future research are provided and their practical implications considered.
\end{abstract}

Keywords: health information seeking, the elderly, health anxiety, common-sense model of self-regulation, cyberchondria

Primljeno: 19.11.2019. 